BENTHM OPEN
CrossMark
Content list available at: www.benthamopen.com/TOCMJ/
DOI: $10.2174 / 1874192401610010057$

\title{
Does Stroke Volume Increase During an Incremental Exercise? A Systematic Review
}

\author{
Stella S. Vieira ${ }^{1}$, Brunno Lemes ${ }^{1}$, Paulo de T. C. de Carvalho ${ }^{2}$, Rafael N. de Lima ${ }^{2}$, Danilo S. \\ Bocalini ${ }^{3}$, José A. S. Junior ${ }^{4}$, Gisela Arsa ${ }^{5}$, Cezar A. Casarin ${ }^{2}$, Erinaldo L. Andrade ${ }^{3}$ and Andrey J. \\ Serra $^{2, *}$ \\ ${ }^{I}$ Universidade Federal de São Paulo, Laboratório de Fisiologia e Fisiopatologia Cardíaca, São Paulo, SP, Brazil \\ ${ }^{2}$ Universidade Nove de Julho, Programa de Pós-Graduação em Biofotônica Aplicada a Ciências da Saúde, São Paulo, \\ SP, Brazil \\ ${ }^{3}$ Laboratorio de Fisiologia Transacional dos Programas de Pos Graduacao em Educacao Fisica e Ciências do En- \\ velhecimento, São Paulo, SP, Brasil \\ ${ }^{4}$ Universidade Nove de Julho, Programa de Pós-Graduação em Medicina, São Paulo, SP, Brazil \\ ${ }^{5}$ Universidade Federal do Mato Grosso, Programa de Mestrado em Educação Física, Cuiabá, MT, Brazil
}

Received: August 22, 2015

Revised: September 20, 2015

Accepted: October 22, 2015

Abstract:

Introduction:

Cardiac output increases during incremental-load exercise to meet metabolic skeletal muscle demand. This response requires a fast adjustment in heart rate and stroke volume. The heart rate is well known to increase linearly with exercise load; however, data for stroke volume during incremental-load exercise are unclear. Our objectives were to (a) review studies that have investigated stroke volume on incremental load exercise and (b) summarize the findings for stroke volume, primarily at maximal-exercise load.

\section{Methods:}

A comprehensive review of the Cochrane Library's, Embase, Medline, SportDiscus, PubMed, and Web of Sci-ence databases was carried out for the years 1985 to the present. The search was performed between February and June 2014 to find studies evaluating changes in stroke volume during incremental-load exercise. Controlled and uncontrolled trials were evaluated for a quality score.

Results:

The stroke volume data in maximal-exercise load are inconsistent. There is evidence to hypothesis that stroke volume increases during maximal-exercise load, but other lines of evidence indicate that stroke volume reaches a plateau under these circumstances, or even decreases.

\section{Conclusion:}

The stroke volume are unclear, include contradictory evidence. Additional studies with standardized reporting for subjects (e.g., age, gender, physical fitness, and body position), exercise test protocols, and left ventricular function are required to clarify the characteristics of stroke volume during incremental maximal-exercise load.

Keywords: Aerobic exercise, cardiac function, heart physiology, incremental exercise, maximal-exercise load, stroke volume.

\footnotetext{
* Address correspondence to this author at the Vergueiro 235/249, Zip code: 01504-000, São Paulo, SP, Brazil; Tel: (55 11-50833735); E-mail: andreyserra@gmail.com
} 


\section{INTRODUCTION}

The cardiac performance is based on satisfactory left ventricular (LV) function to ensure a blood output to all tissues. Thus, LV function increases to maintain homeostasis according to metabolic load [1]. During an incrementalload exercise, cardiac output should increase to meet the extraordinary blood demands of the working musculature. This additional blood flow provides the major capability for acting exercise. The manner in which the LV responds to the strain of exercise has intrigued physiologists. In fact, exercise training requires a fast adjustment in heart rate and stroke volume (SV) [1].

The heart rate is a mechanism by which cardiac output rises during effort under physiological conditions. It is well known that heart rate increases linearly with exercise load because of an imbalance between sympathetic and parasympathetic autonomic nervous activity. There are two major mechanisms by which tachycardia occurs during incremental exercise: (1) decreased parasympathetic restraint and (2) increased sympathetic drive. The SV increase is linked to two different situations: (1) low-exercise load, in which the Frank-Starling mechanism has a key role and (2) increased myocardial contractility, shown to occur under maximal-load exercise (MLE) [2,3].

Currently, the nonlinear SV response to increases in the exercise load is an issue of interest. Studies using several experimental approaches have shown decreases, plateaus, or increases SV during MLE. In the light of these findings, this systematic review incorporates original articles that assessed changes in SV during incremental-load exercise, to exhaustion, in healthy adult humans.

\section{MATERIALS AND METHODS}

\section{Search Procedure}

A comprehensive review was carried out of the Cochrane Library's, Embase, Medline, SportDiscus, PubMed, and Web of Science databases for studies published since 1985. The search was based on the following keywords and MeSH terms: aerobic exercise, cardiac output, dynamic exercise, incremental exercise, health subjects, hemodynamic, maximal effort, stroke volume, and systolic function. The search sentences were combined to increase the results.

The survey was carried out between February and June 2014. All studies evaluating the changes in SV during an incremental-load exercise were selected. Two independent researchers using a double-blind approach performed the analyses. The first step of the search was to analyze the abstracts in the database according to the following criteria: participant profile, trial design, exercise test procedure, and SV evaluate approch.

\section{Inclusion and Exclusion Criteria}

Controlled and uncontrolled trials published in peer-reviewed journals were included. We included only trials published in English, conducted on healthy subjects, and which included full information about the physical test procedure and approach used to measure SV. Trials containing supplemented diets, diseased subjects, reviews, and case reports were excluded because they did not express the normal baselines. Studies that did not report their experimental design or outcomes were also excluded.

Studies without clear detailing of SV approaches, as well as exercise protocol were excluded. We evaluated only studies that assessed SV up to a MLE. All eligible articles were reviewed and critically evaluated for quality scores, as previously reported in detail $[4,5]$.

\section{RESULTS}

the Details for screened studies are shown in Fig. (1). In the first screening, we have found 336 articles there were no differences in database search between the two researchers. The abstracts were used to examine duplication in the database. After a search filter application, 144 studies were found. Of these, 131 articles were excluded because they did not meet the eligibility criteria or quality scores.

A total of 13 articles were selected for critical data analysis, and the results are shown in Table 1. Several different incremental exercise-load protocols were used in these studies to induce a maximum effort level. In summary, ten studies measured effort level on a cycle ergometer, two with treadmill running, and one with a 100-drop-jumps protocol. Moreover, the studies used several approaches to evaluate SV. Four studies used cardiac impedance, three used acetylene rebreathing, two used radionuclide ventriculography, and three used catheterization. Only one study applied a predictive equation to evaluate SV. In respect to LV performance, we found conflicting information for SV 
during MLE. Several investigations found a SV plateau at a submaximal-exercise load, [6 - 10] followed by a $40 \%$-50\% decrease in $\mathrm{VO}_{2} \max$ or a decrease in heart rate of $120 \mathrm{bpm}[6-10,13]$. These findings applied mostly to sedentary and moderately active subjects. On the other hand, athletes showed an increased SV during MLE [13 - 15].

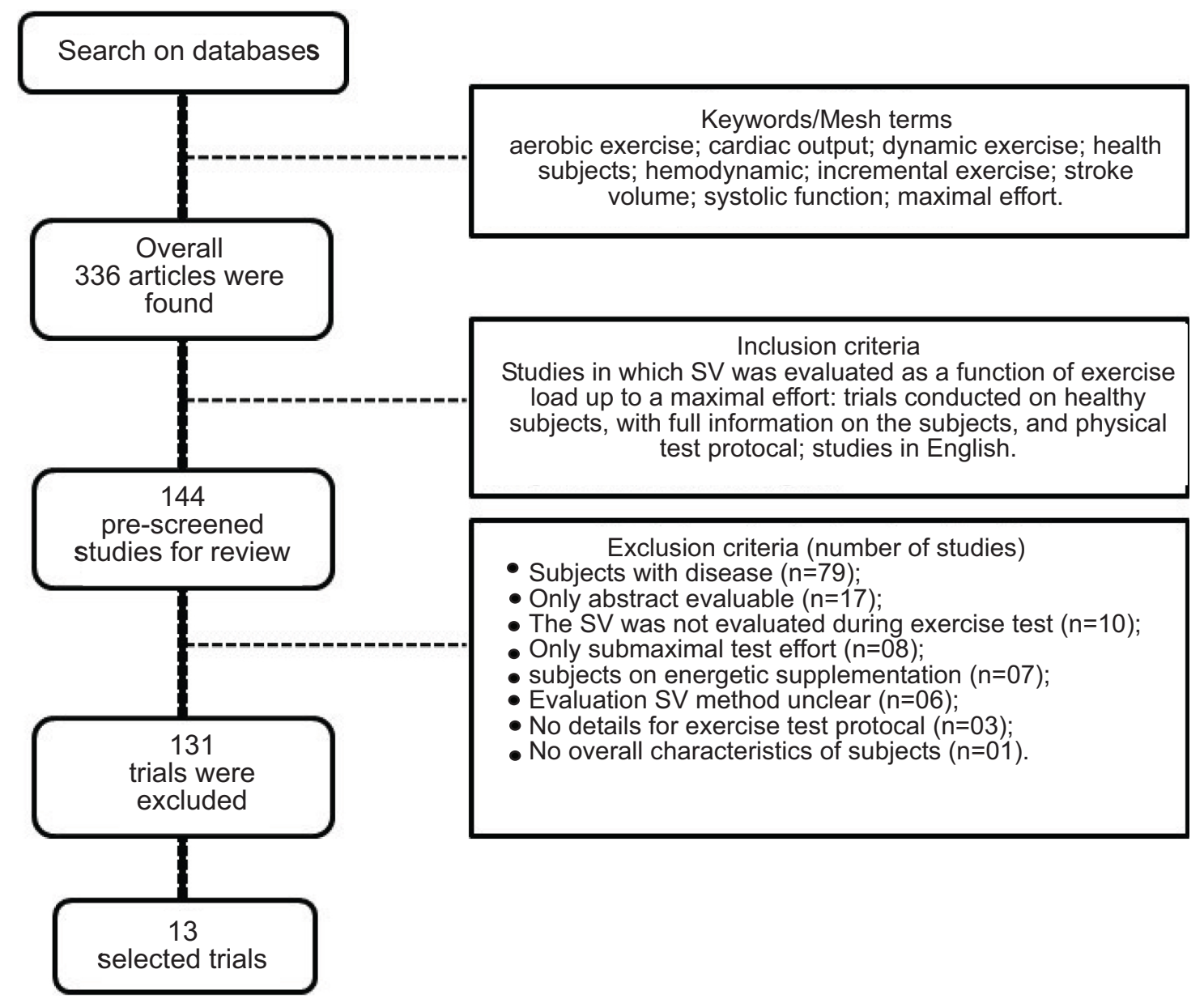

Fig. (1). Flow diagram for search procedure and selection of manuscript included in the systematic review.

\section{DISCUSSION}

This study is the first systematic review to evaluate SV changes during incremental-load exercise. Overall, we found conflicting information regarding SV during MLE. The available evidence shows an increase, as well as a plateau or a decrease, in SV.

Gledhill et al. [15] support the hypothesis that trained subjects show an increased SV during MLE, whereas untrained subjects show a plateau at an early phase of exercise with the same exercise load. Several lines of evidence indicate $\mathrm{SV}$ increases to between $91 \%$ and $100 \%$ of $\mathrm{VO}_{2} \max$ in endurance athletes [16 - 22]. In contrast, there are doubts to SV during MLE in moderately trained subjects, with an SV plateau at submaximal-exercise intensity [23]. We found only one study that showed an increase in SV in nonathletic subjects [24]. This evidence indicates that a high level of physical fitness may be required to obtain increased SV during MLE.

Several mechanisms have been related to a higher SV in athletes during MLE (Fig. 2): increased diastolic filling, LV cavity dimensions, E/A ratio and transmittal pressure gradient, improved myocardial compliance, developed pressure rate $(\mathrm{dP} / \mathrm{dt})$, and sarcoplasmic reticulum function $[15,16,21,25,26]$.

In respect to a SV plateau (Fig. 2), two issues have been shown to be important [6 - 11, 15]: (1) at a low-exercise load, LV filling pressure and end-diastolic volume (Frank-Starling mechanism) increases are linked to a higher SV; (2) at a high workload, an increased heart rate is followed by a decrease in the end-diastolic volume despite an increase in filling pressure. Therefore, SV may be sustained by a decrease in the LV end-systolic volume. 
Table 1. Studies enrolled in the systematic review.

\begin{tabular}{|c|c|c|c|c|}
\hline Trials & Sample & Exercise Protocol & SV Approach & Result \\
\hline $\begin{array}{l}\text { Fukuda et al. }(2010), \\
\text { Japan }\end{array}$ & 9 untrained men $(30.3 \pm 8.5 \mathrm{yr})$ & Cycle ergometer & Cardiac impedance & SV increased on MLE \\
\hline $\begin{array}{c}\text { Lewis et al. (2008), } \\
\text { USA }\end{array}$ & 8 active men $(20.7 \pm 0.4 \mathrm{yr})$ & Cycle ergometer & Cardiac impedance & SV increased on MLE \\
\hline $\begin{array}{l}\text { Marcora et al. (2008), } \\
\text { England }\end{array}$ & 10 active men $(23 \pm 4 \mathrm{yr})$ & $\begin{array}{l}\text { 100-drop-jumps } \\
\text { protocol }\end{array}$ & Cardiac impedance & SV reached a plateau on SLE \\
\hline $\begin{array}{l}\text { Stickland et al. (2006), } \\
\text { Canada }\end{array}$ & 8 active men $(29.7 \pm 2 \mathrm{yr})$ & Cycle ergometer & $\begin{array}{l}\text { Radial artery catheter and a } \\
\text { Swan-Ganz catheter }\end{array}$ & \begin{tabular}{|c} 
Subjects with $\mathrm{VO}_{2} \max <$ \\
$55 \mathrm{ml} \cdot \mathrm{kg}^{-1} \cdot \mathrm{min}^{-1}$ showed a \\
plateau or a decrease in the SV \\
on SLE. Subjects with $\mathrm{VO}_{2} \mathrm{max}$ \\
$>55 \mathrm{ml} \cdot \mathrm{kg}^{-1} \cdot \mathrm{min}^{-1}$ showed SV \\
increases on MLE
\end{tabular} \\
\hline $\begin{array}{c}\text { Stringer et al. }(2005), \\
\text { USA }\end{array}$ & $\begin{array}{c}5 \text { active men }(25 \text { style }=\text { "background- } \\
\text { color: white" }> \pm 6 \text { yr })\end{array}$ & Cycle ergometer & $\begin{array}{c}\text { Cardiac catheterization by } \\
\text { flow-directed balloon } \\
\text { catheter }\end{array}$ & $\begin{array}{l}\text { SV reached a plateau on SLE; } \\
\text { SV decreased on MLE }\end{array}$ \\
\hline $\begin{array}{c}\text { Dufour et al. }(2004), \\
\text { France }\end{array}$ & 8 active men $(28 \pm 2 \mathrm{yr})$ & Cycle ergometer & Cardiac impedance & SV reached a plateau on SLE \\
\hline $\begin{array}{l}\text { Warburton et al. } \\
\text { (2002), Canada }\end{array}$ & 10 trained men cyclists & Cycle ergonometer & $\begin{array}{c}\text { Radionuclide } \\
\text { ventriculography }\end{array}$ & SV increased on MLE \\
\hline $\begin{array}{l}\text { Zhou et al. (2001), } \\
\text { USA }\end{array}$ & $\begin{array}{c}5 \text { elite runner men }(29.8 \pm 5.2 \mathrm{yr}) ; 10 \\
\text { university runner men }(25.5 \pm 4.3 \mathrm{yr}) \\
10 \text { untrained men }(28.1 \pm 7.5 \mathrm{yr})\end{array}$ & Treadmill running & Acetylene rebreathing & $\begin{array}{c}\text { Untrained and moderately } \\
\text { active subjects: SV reached } \\
\text { plateau on SLE. Elite athletes: } \\
\text { SV increased on MLE }\end{array}$ \\
\hline $\begin{array}{c}\text { McCole et al. (1999), } \\
\text { USA }\end{array}$ & $\begin{array}{c}24 \text { women: } 8 \text { sedentary, } 10 \text { active, and } \\
6 \text { master athletes }(63 \pm 5 \mathrm{yr})\end{array}$ & Treadmill running & Acetylene rebreathing & SV decreased on SLE \\
\hline $\begin{array}{c}\text { Stringer et al. (1997), } \\
\text { USA }\end{array}$ & 5 active men $(25 \pm 6 \mathrm{yr})$ & Cycle ergometer & $\begin{array}{l}\text { EQUAL: SV was estimated } \\
\quad \text { if the } \mathrm{C}(\mathrm{a}-\mathrm{vDO} 2)\end{array}$ & $\begin{array}{c}\text { SV reached a plateau on } \\
\text { submaximal exercise load; SV } \\
\text { decreased on MLE }\end{array}$ \\
\hline $\begin{array}{l}\text { Gledhill et al. (1994), } \\
\text { Canada }\end{array}$ & $\begin{array}{c}7 \text { trained men }(22.5 \pm 2.1 \mathrm{yr}) \text { and } 7 \\
\text { untrained men }(22.2 \pm 4.9 \mathrm{yr})\end{array}$ & Cycle ergometer & Acetylene rebreathing & $\begin{array}{c}\text { Untrained: SV reached a plateau } \\
\text { with } 120 \text { bpm. Trained: SV } \\
\text { increased until the HRmax }\end{array}$ \\
\hline $\begin{array}{c}\text { Stratton et al. (1994), } \\
\text { USA }\end{array}$ & $\begin{array}{c}17 \text { young }(28 \pm 3 \mathrm{yr}) \text { and } 15 \text { active old } \\
\text { men }(68 \pm 6 \mathrm{yr})\end{array}$ & Cycle ergometer & $\begin{array}{c}\text { Radionuclide } \\
\text { ventriculography }\end{array}$ & $\begin{array}{l}\text { SV reached a plateau on SLE; } \\
\text { SV decreased on MLE }\end{array}$ \\
\hline $\begin{array}{l}\text { Higginbotham et al. } \\
\text { (1986), USA }\end{array}$ & $\begin{array}{l}24 \text { men: } 9 \text { active and } 15 \text { sedentary } \\
(20-50 \mathrm{yr})\end{array}$ & Cycle ergometer & $\begin{array}{l}\text { Cardiac catheterization by } \\
\text { 7-French balloon-tipped } \\
\text { thermodilution Swan-Ganz } \\
\text { catheter }\end{array}$ & SV reached a plateau on SLE \\
\hline
\end{tabular}

bpm, beats per minute; HRmax, maximal heart rate; MLE, maximal load exercise; SLE, submaximal load exercise; SV, stroke volume; VO max, maximal oxygen consumption.

Authors whose results support a lower SV during MLE report that the decline coincides with a plateau or decrease in cardiac output, resulting from the regulatory limitations of the heart (Fig. 2) [12]. This decrease is linearly related to increases in core temperature, catecholamines, heart rate, and blood pressure. Hence, SV declines could be a result of several factors linked to a preload depression of and/or decrease in LV ejection [27]. Moreover, one line of evidence supports the hypothesis that SV reduction during MLE could be related to the restrictions on LV filling time and LV end-diastolic volume that accompany tachycardia [28]. Cardiovascular strain associated with dehydration and hyperthermia may also decrease SV [29, 30].

In summary, studies have shown increases, plateaus, and decreases in SV during exercise at submaximal to maximal workloads. These findings are clearly inconsistent and must be resolved by future investigations. Our analysis can help to explain the divergent results. A detailed article analysis revealed the several exercise protocols were applied to induce high SV levels. Moreover, several approches (e.g. invasive/noinavsive) were used to evaluate SV. A more detailed analysis of the results in Table $\mathbf{1}$ shows that the available data were obtained from subjects differing in age, gender, physical fitness level, and body position during the experiments. As LV function is known to be affected significantly by these factors $[21,31,32]$, it remains unclear how SV changes during MLE. 


\section{LIMITATIONS OF CURRENT KNOWLEDGE}

As a systematic review, our study cannot disregard the design and/or execution problems linked to selected primary studies. Moreover, it is possible that the lack of study homogeneity may have influenced the interpretation of the results. Thus, limitations relating to the heterogeneity of approaches to SV analysis should also be exposed; some results may be inconclusive when several studies are compared to each other. These issues show to be considered for the current knowledge on the SV performance during exercise at submaximal to maximal loads. Ultimately, we only included studies published in English, which may have excluded relevant studies in other languages.

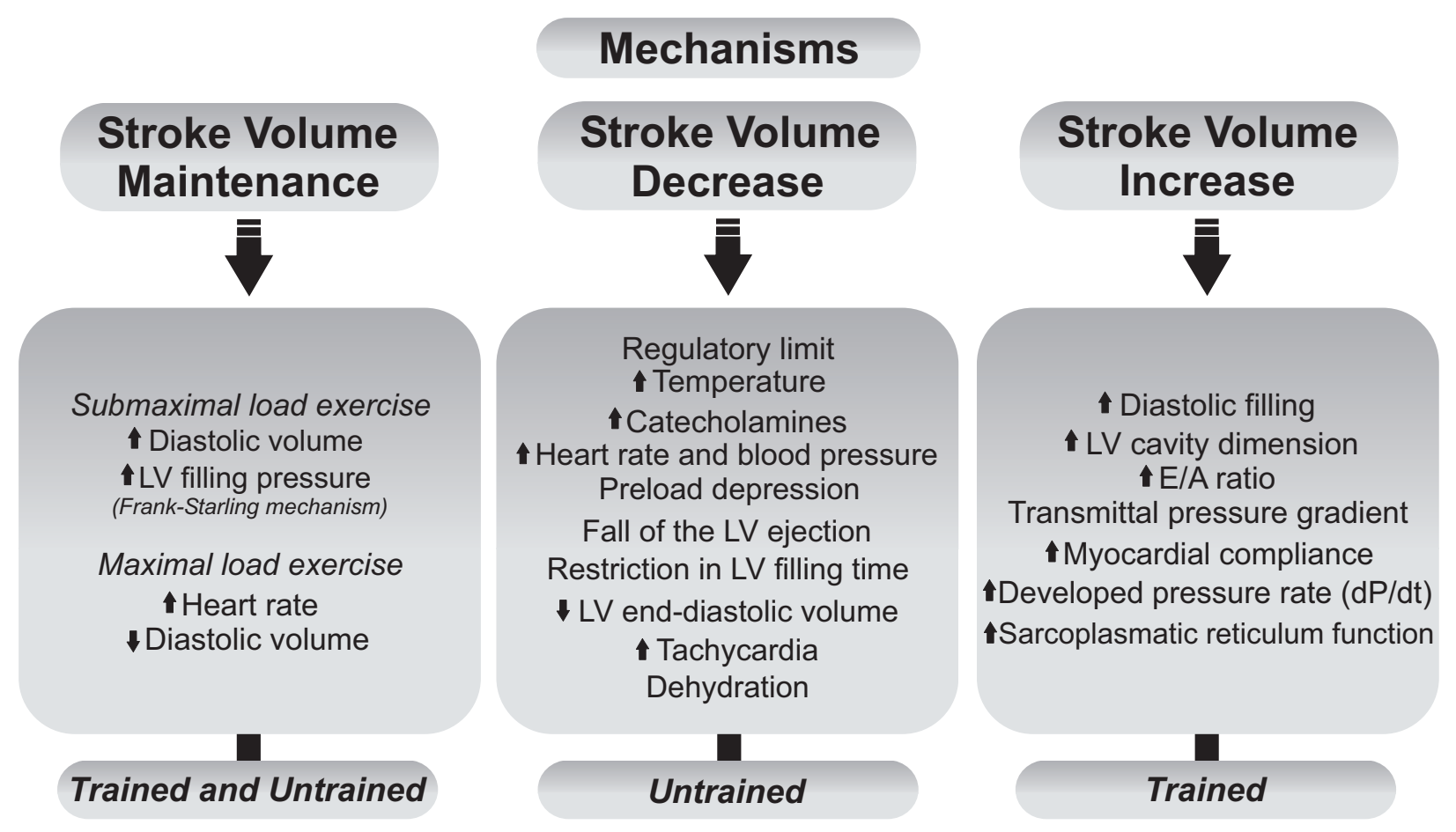

Fig. (2). Regulatory stroke volume mechanisms under low/moderate and high exercise loads.

\section{CONFLICT OF INTEREST}

The authors confirm that this article content has no conflict of interest.

\section{ACKNOWLEDGEMENTS}

This work was partially supported by grant number 479395/2012-8, National Council for Scientific. The funders had no role in study design, data collection and analysis, decision to publish, or preparation of the manuscript. The authors are grateful to American Manuscript Editors for professionally editing this paper.

\section{REFERENCES}

[1] Powers SK, Howley ED. Exercise physiology: theory and application to fitness and performance. $5^{\text {th }}$ ed. Boston: McGraw-Will 2004.

[2] Steingart RM, Wexler J, Slagle S, Scheuer J. Radionuclide ventriculographic responses to graded supine and upright exercise: critical role of the Frank-Starling mechanism at submaximal exercise. Am J Cardiol 1984; 53(11): 1671-7. [http://dx.doi.org/10.1016/0002-9149(84)90600-3] [PMID: 6731313]

[3] Whyte G, Lumley S, George K, et al. Physiological profile and predictors of cycling performance in ultra-endurance triathletes. J Sports Med Phys Fitness 2000; 40(2): 103-9.

[PMID: 11034429]

[4] Oxman AD, Guyatt GH, Singer J, et al. Agreement among reviewers of review articles. J Clin Epidemiol 1991; 44(1): 91-8. [http://dx.doi.org/10.1016/0895-4356(91)90205-N] [PMID: 1824710]

[5] Oxman AD, Guyatt GH. Validation of an index of the quality of review articles. J Clin Epidemiol 1991; 44(11): 1271-8. [http://dx.doi.org/10.1016/0895-4356(91)90160-B] [PMID: 1834807]

[6] Stratton JR, Levy WC, Cerqueira MD, Schwartz RS, Abrass IB. Cardiovascular responses to exercise. Effects of aging and exercise training 
in healthy men. Circulation 1994; 89(4): 1648-55.

[http://dx.doi.org/10.1161/01.CIR.89.4.1648] [PMID: 8149532]

[7] Stringer WW, Hansen JE, Wasserman K. Cardiac output estimated noninvasively from oxygen uptake during exercise. J Appl Physiol 1997; 82(3): 908-12.

[PMID: 9074981]

[8] Dufour SP, Lampert E, Doutreleau S, et al. Eccentric cycle exercise: training application of specific circulatory adjustments. Med Sci Sports Exerc 2004; 36(11): 1900-6. [http://dx.doi.org/10.1249/01.MSS.0000145441.80209.66] [PMID: 15514505]

[9] Stringer WW, Whipp BJ, Wasserman K, Pórszász J, Christenson P, French WJ. Non-linear cardiac output dynamics during ramp-incremental cycle ergometry. Eur J Appl Physiol 2005; 93(5-6): 634-9.

[http://dx.doi.org/10.1007/s00421-004-1258-3] [PMID: 15578205]

[10] Marcora SM, Bosio A, de Morree HM. Locomotor muscle fatigue increases cardiorespiratory responses and reduces performance during intense cycling exercise independently from metabolic stress. Am J Physiol Regul Integr Comp Physiol 2008; 294(3): R874-83. [http://dx.doi.org/10.1152/ajpregu.00678.2007] [PMID: 18184760]

[11] Higginbotham MB, Morris KG, Williams RS, McHale PA, Coleman RE, Cobb FR. Regulation of stroke volume during submaximal and maximal upright exercise in normal man. Circ Res 1986; 58(2): 281-91. [http://dx.doi.org/10.1161/01.RES.58.2.281] [PMID: 3948345]

[12] McCole SD, Brown MD, Moore GE, Zmuda JM, Cwynar JD, Hagberg JM. Cardiovascular hemodynamics with increasing exercise intensities in postmenopausal women. J Appl Physiol 1999; 87(6): 2334-40. [PMID: 10601186]

[13] Zhou B, Conlee RK, Jensen R, Fellingham GW, George JD, Fisher AG. Stroke volume does not plateau during graded exercise in elite male distance runners. Med Sci Sports Exerc 2001; 33(11): 1849-54. [http://dx.doi.org/10.1097/00005768-200111000-00008] [PMID: 11689734]

[14] Lewis SF, Taylor WF, Graham RM, Pettinger WA, Schutte JE, Blomqvist CG. Cardiovascular responses to exercise as functions of absolute and relative work load. J Appl Physiol 1983; 54(5): 1314-23.

[PMID: 6863092]

[15] Gledhill N, Cox D, Jamnik R. Endurance athletes'stroke volume does not plateau: major advantage is diastolic function. Med Sci Sports Exerc 1994; 26(9): 1116-21. [http://dx.doi.org/10.1249/00005768-199409000-00008] [PMID: 7808245]

[16] Krip B, Gledhill N, Jamnik V, Warburton D. Effect of alterations in blood volume on cardiac function during maximal exercise. Med Sci Sports Exerc 1997; 29(11): 1469-76. [http://dx.doi.org/10.1097/00005768-199711000-00013] [PMID: 9372484]

[17] Wiebe CG, Gledhill N, Warburton DE, Jamnik VK, Ferguson S. Exercise cardiac function in endurance-trained males versus females. Clin J Sport Med 1998; 8(4): 272-9.

[http://dx.doi.org/10.1097/00042752-199810000-00004] [PMID: 9884791]

[18] Wiebe CG, Gledhill N, Jamnik VK, Ferguson S. Exercise cardiac function in young through elderly endurance trained women. Med Sci Sports Exerc 1999; 31(5): 684-91. [http://dx.doi.org/10.1097/00005768-199905000-00010] [PMID: 10331888]

[19] Warburton DE, Gledhill N, Jamnik VK, Krip B, Card N. Induced hypervolemia, cardiac function, VO2max, and performance of elite cyclists. Med Sci Sports Exerc 1999; 31(6): 800-8. [http://dx.doi.org/10.1097/00005768-199906000-00007] [PMID: 10378906]

[20] Ferguson S, Gledhill N, Jamnik VK, Wiebe C, Payne N. Cardiac performance in endurance-trained and moderately active young women. Med Sci Sports Exerc 2001; 33(7): 1114-9.

[http://dx.doi.org/10.1097/00005768-200107000-00008] [PMID: 11445758]

[21] Warburton DE, Haykowsky MJ, Quinney HA, Blackmore D, Teo KK, Humen DP. Myocardial response to incremental exercise in endurancetrained athletes: influence of heart rate, contractility and the Frank-Starling effect. Exp Physiol 2002; 87(5): 613-22. [http://dx.doi.org/10.1113/eph8702372] [PMID: 12481936]

[22] Stickland MK, Welsh RC, Petersen SR, et al. Does fitness level modulate the cardiovascular hemodynamic response to exercise? J Appl Physiol 2006; 100(6): 1895-901.

[http://dx.doi.org/10.1152/japplphysiol.01485.2005] [PMID: 16497838]

[23] Spriet LL, Gledhill N, Froese AB, Wilkes DL. Effect of graded erythrocythemia on cardiovascular and metabolic responses to exercise. J Appl Physiol 1986; 61(5): 1942-8.

[PMID: 3781999]

[24] Fukuda T, Maegawa T, Matsumoto A, et al. Effects of acute hypoxia at moderate altitude on stroke volume and cardiac output during exercise. Int Heart J 2010; 51(3): 170-5. [http://dx.doi.org/10.1536/ihj.51.170] [PMID: 20558906]

[25] Gledhill N, Warburton D, Jamnik V. Haemoglobin, blood volume, cardiac function, and aerobic power. Can J Appl Physiol 1999; 24(1): 54-65. 
[http://dx.doi.org/10.1139/h99-006] [PMID: 9916181]

[26] Sundstedt M, Hedberg P, Jonason T, Ringqvist I, Henriksen E. Echocardiographic Doppler assessments of left ventricular filling and ejection during upright exercise in endurance athletes. Clin Physiol Funct Imaging 2007; 27(1): 36-41. [http://dx.doi.org/10.1111/j.1475-097X.2007.00715.x] [PMID: 17204036]

[27] González-Alonso J. Point: Stroke volume does/does not decline during exercise at maximal effort in healthy individuals. J Appl Physiol 2008; 104(1): 275-6.

[http://dx.doi.org/10.1152/japplphysiol.00595.2007] [PMID: 17569765]

[28] González-Alonso J, Calbet JA. Reductions in systemic and skeletal muscle blood flow and oxygen delivery limit maximal aerobic capacity in humans. Circulation 2003; 107(6): 824-30. [http://dx.doi.org/10.1161/01.CIR.0000049746.29175.3F] [PMID: 12591751]

[29] González-Alonso J, Calbet JA, Nielsen B. Muscle blood flow is reduced with dehydration during prolonged exercise in humans. J Physiol 1998; 513(Pt 3): 895-905.

[http://dx.doi.org/10.1111/j.1469-7793.1998.895ba.x] [PMID: 9824726]

[30] González-Alonso J, Mora-Rodríguez R, Coyle EF. Stroke volume during exercise: interaction of environment and hydration. Am J Physiol Heart Circ Physiol 2000; 278(2): H321-30. [PMID: 10666060]

[31] Esch BT, Bredin SS, Haykowsky MJ, Scott JM, Warburton DE. The potential role of the pericardium on diastolic filling in endurance-trained athletes under conditions of physiological stress. Appl Physiol Nutr Metab 2007; 32(2): 311-7. [http://dx.doi.org/10.1139/h06-086] [PMID: 17486175]

[32] Warburton DE, Gledhill N. Counterpoint: Stroke volume does not decline during exercise at maximal effort in healthy individuals. J Appl Physiol 2008; 104(1): 276-8.

[http://dx.doi.org/10.1152/japplphysiol.00595.2007a] [PMID: 18198286]

C) Vieira et al.; Licensee Bentham Open.

This is an open access article licensed under the terms of the Creative Commons Attribution-Non-Commercial 4.0 International Public License (CC BY-NC 4.0) (https://creativecommons.org/licenses/by-nc/4.0/legalcode), which permits unrestricted, non-commercial use, distribution and reproduction in any medium, provided the work is properly cited. 